\title{
Physicochemical and Atomic Characterization of Silver Powder after Biofield Treatment
}

\author{
Mahendra Kumar Trivedi ${ }^{1}$, Rama Mohan Tallapragada ${ }^{1}$, Alice Branton ${ }^{1}$, Dahryn Trivedi $^{1}$, Gopal Nayak ${ }^{1}$, Omprakash Latiyal ${ }^{2}$ and Snehasis \\ Jana ${ }^{2 *}$ \\ ${ }^{1}$ Trivedi Global Inc., 10624 S Eastern Avenue Suite A-969, Henderson, NV 89052, USA \\ ${ }^{2}$ Trivedi Science Research Laboratory Pvt. Ltd., Hall-A, Chinar Mega Mall, Chinar Fortune City, Hoshangabad Road, Bhopal- 462026, Madhya Pradesh, India
}

\begin{abstract}
Silver is widely utilized as antimicrobial agent and wound dressing, where its shape, size, surface area, and surface charge play an important role. The aim of present study was to evaluate the impact of biofield treatment on physicochemical and atomic properties of silver powder. The silver powder was divided into two groups, coded as control and treatment. The treatment group received Mr. Trivedi's biofield treatment. Subsequently, control and treated samples were characterized using particle size analyzer, X-ray diffraction (XRD) and surface area analyser. Particle size data exhibited that particle sizes $d_{10}, d_{50}, d_{90}$, and $d_{99}$ (Size, below which 10,50,90, and $99 \%$ particle are present, respectively) of treated silver powder were substantially reduced up to $95.8,89.9,83.2$, and $79.0 \%$ on day 84 as compared to control. XRD results showed that lattice parameter, unit cell volume, and atomic weight were reduced, whereas density and nuclear charge per unit volume were found to be increased as compared to control. In addition, the crystallite size was significantly reduced up to $70 \%$ after biofield treatment on day 105 as compared to control. Furthermore, the surface area of treated silver powder was substantially enhanced by $49.41 \%$ on day 68 as compared to control. These findings suggest that biofield treatment has significantly altered the atomic and physicochemical properties which could make silver more useful in antimicrobial applications.
\end{abstract}

Keywords: Biofield treatment; Silver; X-ray Diffraction; Particle size;

Surface area

\section{Introduction}

Silver (Ag), a white, lustrous transition metal, known for its high electrical conductivity, reflectivity, and thermal conductivity. It exists in form of face centred cubic (FCC) crystal structure. Silver is widely used for electrical applications, filler material in conductive polymer, solar photovoltaic panel etc. [1]. Besides this, silver and silver-based compounds have been used in several antimicrobial applications [2]. Guggenbichler et al. reported that silver has most effective antibacterial action and least toxicity to animal cell [3]. Silver ions $\left(\mathrm{Ag}^{+}\right)$are microcidal at low concentration, which can be used to treat burns, wounds and ulcers. In addition, silver is also used in various hygiene products including face creams, health supplements, and water filtration cartridges [4]. Silver nanoparticles are gaining tremendous attention due to its capability of modulating the chemical, physical, antimicrobial, and optical properties. Furthermore, it is well established that uniform sized particles, with required shape, physical and chemical properties are of great interest in the formulation of new pharmaceutical products [5]. Besides, silver nanoparticles can be synthesised through various techniques such as sol gel, reverse micelle, intern gas condensation, and sonochemistry, etc, but many of these techniques either use hazardous or expensive chemicals [6]. Moreover, in physical condensation process a tube furnace is used, which occupies a large space and require large amount of thermal power [7]. Whereas, in chemical synthesis approach, the use of strong reducing agent such as borohydride results into smaller particles but it is difficult to control over large particle [8]. Thus, after considering properties and biological applications of silver, authors wanted to investigate an economically safe approach that could be beneficial to modify the physical and structural properties of silver powder.

The law of mass-energy inter-conversion has existed in the literature for more than 300 years for which first idea was given by Hasenohrl, after that Einstein derived the well-known equation $E=m c^{2}$ for light and mass $[9,10]$. Furthermore, the energy exists in various forms and there are several ways to transfer the energy from one place to another such as electromagnetic waves, electrochemical, electrical and thermal etc. Similarly, the human nervous system consists of neurons, which have the ability to transmit information and energy in the form of electrical signals [11]. Thus, a human has ability to harness the energy from environment/universe and it can transmit into any object (living or non-living) on the Globe. The object always receives the energy and responded into useful way and that is called biofield energy. This process is known as biofield treatment. Mr. Trivedi's biofield treatment has known to transform the characteristics in various fields such as material science [12,13], microbiology [14-16], biotechnology [17,18], and agriculture [19-21]. In metals and ceramics the biofield treatment has shown the excellent results at physical, thermal, and atomic level $[22,23]$. In addition to this, the biofield treatment had increased the crystallite size and particle size by two folds and six folds, respectively in carbon allotropes [24]. Based on the outstanding results achieved by biofield treatment on metals and ceramics, an attempt was made to evaluate the effect of biofield treatment on atomic and physicochemical properties of silver powder.

*Corresponding author: Dr. Snehasis Jana, Trivedi Science Research Laboratory Pvt. Ltd., Hall-A, Chinar Mega Mall, Chinar Fortune City, Hoshangabad Road, Bhopal- 462026, Madhya Pradesh, India, Tel:+91-755-6660006; E-mail: publication@trivedisrl.com

Received: July 24, 2015; Accepted: September 16, 2015; Published: September 28, 2015

Citation: Trivedi MK, Tallapragada RM, Branton A, Trivedi D, Nayak G, et al (2015) Physicochemical and Atomic Characterization of Silver Powder after Biofield Treatment. J Bioengineer \& Biomedical Sci 5: 165. doi:10.4172/2155 9538.1000165

Copyright: (c) 2015 Trivedi MK, et al. This is an open-access article distributed under the terms of the Creative Commons Attribution License, which permits unrestricted use, distribution, and reproduction in any medium, provided the original author and source are credited. 


\section{Experimental}

Silver powder used in present investigation was procured from MEPCO, India. Silver powder was divided into two parts, referred as control and treated. The treated part was received Mr. Trivedi's biofield treatment. Control and treated samples were characterized using particle size analyzer, X-ray diffraction (XRD), and surface area analyzer at different time periods.

\section{Particle size analysis}

Particle size analyzer, Sympatec HELOS-BF was used to determine the particle size distribution. This system can detect the particle of size from $0.1 \mu \mathrm{m}$ to $875 \mu \mathrm{m}$. The data obtained from the instrument was in the form of a chart of cumulative percentage vs. particle size. Particle sizes $d_{10}, d_{50}, d_{90}$, and $d_{99}$ (size below which 10, 50, 90, and $99 \%$ particle are present, respectively) were computed from particle size distribution curve. Percent change in particle size was calculated using following equations:

$$
\% \text { change in particle size, } \mathrm{d}_{10}=\frac{\left[\left(\mathrm{d}_{10}\right)_{\text {Treated }}-\left(\mathrm{d}_{10}\right)_{\text {Control }}\right]}{\left(\mathrm{d}_{10}\right)_{\text {Control }}} \times 100
$$

Where, $\left(\mathrm{d}_{10}\right)_{\text {Control }}$ and $\left(\mathrm{d}_{10}\right)_{\text {Treated }}$ are the particle size, $\mathrm{d}_{10}$ of control and treated samples respectively. Similarly, the percent change in particle size $\mathrm{d}_{50}, \mathrm{~d}_{90}$, and $\mathrm{d}_{99}$ were calculated.

\section{$\mathrm{X}$-ray diffraction analysis}

$\mathrm{XRD}$ analysis of control and biofield treated silver powder was carried out on Phillips, Holland PW 1710 XRD diffractometer, which had a copper anode with nickel filter. The wavelength of X-ray radiation used was $1.54056 \AA$. Data obtained from the XRD was in chart form of intensity vs. $2 \theta^{\circ}$, with a detailed table containing $\mathrm{d}$ value $(\AA)$, number of peaks, peak width $2 \theta^{\circ}$, peak count, relative intensity of peaks, etc. Further, lattice parameter, unit cell volume, and atomic weight were computed using PowderX software. Atomic weight in g/ mol was calculated as multiplying the atomic weight by the Avogadro number $\left(6.023 \times 10^{23}\right)$. Weight of the unit cell was calculated as, atomic weight multiplied by the number of atoms present in a unit cell. Total nuclear charge was calculated as the number of protons multiplied by charge on a proton $\left(1.6 \times 10^{-19} \mathrm{C}\right)$. Nuclear charge per unit volume was computed as follow:

Nuclear charge per unit volume $=\frac{\text { Total nuclear charge in an atom }}{\text { Volume of an atom }}$
Crystallite size was calculated as follow:

Crystallite size $=\mathrm{k} \lambda / \mathrm{b} \operatorname{Cos} \theta$.

Where, $\lambda$ is the wavelength of $\mathrm{x}$-ray $(=1.54056 \AA)$ and $\mathrm{k}$ is the equipment constant $(=0.94)$.

Besides, the percent change in the lattice parameter was calculated using following equation:

$$
\% \text { change in lattice parameter }=\frac{\left[\mathrm{A}_{\text {Treated }}-\mathrm{A}_{\mathrm{Control}}\right]}{\mathrm{A}_{\mathrm{Control}}} \times 100
$$

Where $\mathrm{A}_{\text {Control }}$ and $\mathrm{A}_{\text {Treated }}$ are the lattice parameter of treated and control samples respectively. Similarly, the percent change in all other parameters such as unit cell volume, density, atomic weight, nuclear charge per unit volume, crystallite size were calculated.

\section{Surface area analysis}

The surface area was measured by the Surface area analyser,
SMART SORB 90 based on Brunauer-Emmett-Teller (BET), which had a detection range of $0 \cdot 2-1000 \mathrm{~m}^{2} / \mathrm{g}$. Percent change in surface area was calculated using following equations:

$$
\% \text { change in surface area }=\frac{\left[\mathrm{S}_{\text {Treated }}-\mathrm{S}_{\text {Control }}\right]}{\mathrm{S}_{\text {Control }}} \times 100
$$

Where, $\mathrm{S}_{\text {Control }}$ and $\mathrm{S}_{\text {Treated }}$ are the surface area of control and treated samples respectively.

\section{Results and Discussion}

\section{Particle size analysis}

The particle size analysis results of $\mathrm{d}_{10}, \mathrm{~d}_{50}, \mathrm{~d}_{90}$, and $\mathrm{d}_{99}$ of silver powder are presented in Table 1. Data showed that the particle size, $\mathrm{d}_{10}$ i.e. smaller size particles of treated silver sample was increased from $47.04 \mu \mathrm{m}$ (control) to $48.73 \mu \mathrm{m}$ on day 10 , whereas it was significantly reduced to $1.97,1.68$, and $1,67 \mu \mathrm{m}$ on day 84,91 , and 109 , respectively. It suggest that $d_{10}$, was substantially decreased by $95.81,96.43$, and $96.45 \%$ on day 84,91 , and 109 respectively as compared to control. Average particle size, $d_{50}$ was significantly reduced from $81.90 \mu \mathrm{m}$ (control) to $79.43,8.31,6.82$, and $6.94 \mu \mathrm{m}$ on day $10,84,91$, and 109 respectively in treated silver sample. It suggest that $d_{50}$ of treated silver sample was substantially reduced by $3.02,89.85,91.67$, and $91.53 \%$ on day $10,84,91$, and 109 , respectively as compared to control. In addition, particle size, $d_{90}$ of treated silver sample was reduced from $124.29 \mu \mathrm{m}$ (control) to $118.71,20.88,17.60$, and $34.59 \mu \mathrm{m}$ on day $10,84,91$, and 109 respectively, which indicated that after biofield treatment, $\mathrm{d}_{90}$ of silver samples were reduced by $4.49,83.20,85.84$, and $72.17 \%$ on day $10,84,91$, and 109 , respectively as compared to control. Furthermore, the particle size $d_{99}$ was significantly reduced from $173.70 \mu \mathrm{m}$ (control) to $154.16,36.55,34.95$, and $61.35 \mu \mathrm{m}$ on day $10,84,91$, and 109 respectively in treated silver sample. It indicated that $\mathrm{d}_{99}$ of treated silver sample was substantially reduced by $11.25,78.96$, 79.88 , and $64.88 \%$ on day $10,84,91$, and 109 respectively as compared to control. Overall, particle size data revealed that biofield treatment has significantly reduced the silver particle size. Our group previously reported that biofield treatment has significantly reduced the particle size in titanium and antimony powder $[12,13]$. Silver particles have high density of point defects, dislocations, grain and interphase boundaries. The boundaries are structurally weak points in silver powder, which can easily fracture under high stress conditions. Thus, it is assumed that biofield treatment probably transfer the stress energy to silver particles, which may results into fracturing of particles and reduced particle size. It is reported that antimicrobial action of silver is depend upon its size i.e smaller the size of silver particles, higher is antimicrobial efficacy in human body $[25,26]$. Further, it is also reported that antimicrobial activity of silver is associated with its ionized form as body fluid ionized the silver $\left(\mathrm{Ag}^{+}\right)$and make it highly reactive. This ionized silver atom binds to tissue protein and change the structure of bacterial cell wall and nuclear membrane, which further leads to cell distortion and death

\begin{tabular}{|c|c|c|c|c|}
\hline Group & $\mathbf{d}_{\mathbf{1 0}}(\boldsymbol{\mu m})$ & $\mathbf{d}_{\mathbf{5 0}}(\boldsymbol{\mu m})$ & $\mathbf{d}_{\mathbf{9 0}}(\boldsymbol{\mu m})$ & $\mathbf{d}_{\mathbf{9 9}}(\boldsymbol{\mu m})$ \\
\hline Control, day 0 & 47.04 & 81.90 & 124.29 & 173.70 \\
\hline Treated, day 10 & 48.73 & 79.43 & 118.71 & 154.16 \\
\hline Treated, day 84 & 1.97 & 8.31 & 20.88 & 36.55 \\
\hline Treated, day 91 & 1.68 & 6.82 & 17.60 & 34.95 \\
\hline Treated, day 109 & 1.67 & 6.94 & 34.59 & 61.35 \\
\hline
\end{tabular}

d10, d50, d90, and d99 are the size below which $10 \%, 50 \%, 90 \%$, and $99 \%$ particles are present, respectively.

Table 1: Effect of biofield treatment on particle size of silver powder. 
Citation: Trivedi MK, Tallapragada RM, Branton A, Trivedi D, Nayak G, et al. (2015) Physicochemical and Atomic Characterization of Silver Powder after Biofield Treatment. J Bioengineer \& Biomedical Sci 5: 165. doi:10.4172/2155- 9538.1000165

Page 3 of 5

\begin{tabular}{|c|c|c|c|c|c|c|}
\hline Group & $\begin{array}{l}\text { Lattice Parameter } \\
\qquad(\AA)\end{array}$ & $\begin{array}{l}\text { Unit Cell Volume } \\
\left.\qquad \times 10^{-23} \mathrm{~cm}^{3}\right)\end{array}$ & $\begin{array}{l}\text { Density } \\
\text { (g/cc) }\end{array}$ & \begin{tabular}{|c|} 
Atomic Weight \\
$(\mathrm{g} / \mathrm{mol})$
\end{tabular} & $\begin{array}{c}\text { Nuclear charge per unit } \\
\text { volume }\left(\mathrm{C} / \mathrm{cm}^{3}\right)\end{array}$ & $\begin{array}{l}\text { Crystallite } \\
\text { Size (nm) }\end{array}$ \\
\hline Control, day 0 & 4.098 & 6.882 & 10.511 & 108.932 & 208619.88 & 72.89 \\
\hline Treated, day 105 & 4.099 & 6.887 & 10.504 & 109.008 & 208473.34 & 21.87 \\
\hline Treated, day 156 & 4.092 & 6.850 & 10.561 & 108.418 & 209609.57 & 31.26 \\
\hline Treated, day 189 & 4.098 & 6.885 & 10.508 & 108.966 & 208555.75 & 62.48 \\
\hline Treated, day 203 & 4.088 & 6.831 & 10.591 & 108.117 & 210190.04 & 27.35 \\
\hline
\end{tabular}

Table 2: Effect of biofield treatment on atomic and structural parameters of silver powder

\begin{tabular}{|c|c|c|c|c|c|}
\hline \multirow{2}{*}{ Group } & \multicolumn{4}{|c|}{ Percent Change } \\
\cline { 2 - 6 } & Lattice Parameter & Unit Cell Volume & Density & $\begin{array}{c}\text { Atomic Weight } \\
\text { Nuclear Charge Per } \\
\text { Unit Volume }\end{array}$ & $\begin{array}{c}\text { Crystallite } \\
\text { Size }\end{array}$ \\
\hline Treated, day 105 & 0.02 & 0.07 & -0.07 & -0.07 & -0.07 \\
\hline Treated, day 156 & -0.16 & -0.47 & -0.47 & -0.47 & -0.03 \\
\hline Treated, day 189 & 0.01 & 0.03 & -0.03 & -0.75 & -0.03 \\
\hline Treated, day 203 & -0.25 & -0.75 & 0.75 & -14.3 \\
\hline
\end{tabular}

Table 3: Effect of biofield treatment on percent change in atomic and structural parameters of silver powder as compared to control.

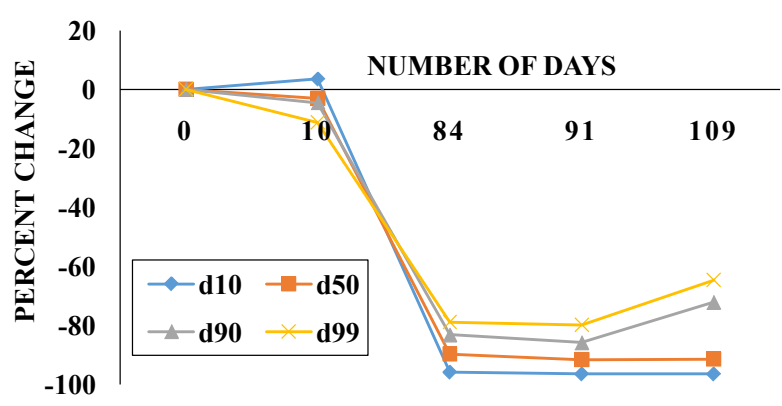

Figure 1: Effect of biofield treatment on particle size of silver powder.

[27]. Further, in order to study the effect of biofield treatment at atomic level, XRD analysis was carried out (Figure 1).

\section{$\mathrm{X}$-ray diffraction analysis}

XRD analysis results of control and treated silver samples are illustrated in Tables 2 and 3. Data showed that the lattice parameter of FCC unit cell of treated silver sample was reduced by 0.16 and $0.25 \%$ on day 105 and 203 respectively, whereas no significant change was observed on day 105 and 189 as compared to control. Furthermore, the unit cell volume was decreased by 0.47 and 0.75 on day 105 and 203 respectively as compared to control. Reduction of unit cell volume leads to increase the density by 0.47 and $0.75 \%$ on day 105 and 203 , respectively as compared to control. Thus, the decrease in unit cell volume and increase in density in treated silver sample indicates that compressive stress may be applied through biofield treatment [28]. Hence, it is assumed that an energy milling might be induced through biofield treatment, which probably provided the high stress and that might be responsible for internal strains in treated silver. Besides, data also showed that atomic weight of treated silver sample was decreased by 0.47 and $0.75 \%$ and nuclear charge per unit volume was increased by 0.47 and $0.75 \%$ on day 105 and 203 , respectively as compared to control. No significant change was observed in lattice parameter, unit cell volume, density, atomic, weight and nuclear charge per unit volume in treated silver sample on day 105 and 189. It is hypothesized that the compressive stress induced through energy milling over unit cell may lead to move the electron cloud toward nucleus from their original position, which may reduce atomic size (volume of the atom) [24]. The reduction of atomic size may increase nuclear charge per unit volume in treated silver since both are inversely related. Previously, our group reported that biofield treatment had increased the nuclear charge per unit volume in zinc and chromium [12]. Moreover, the increase in nuclear charge per unit volume in silver as compared to control indicates that ionic strength of silver $\left(\mathrm{Ag}^{+}\right)$probably enhanced after biofield treatment. It is reported that positive charge of silver ions $\left(\mathrm{Ag}^{+}\right)$plays an important role in antimicrobial activity [29]. Thus, it is assumed that biofield treated silver could exhibit the higher antimicrobial efficacy as compared to control. Besides, the crystallite size of treated silver sample was reduced from $72.89 \mathrm{~nm}$ (control) to $21.87,31.26,62.48$ and $27.35 \mathrm{~nm}$ on day $105,156,189,203$ respectively. Thus, data suggest that crystallite size in treated silver sample was significantly reduced by $70.0,57.1,14.3$, and $62.5 \%$ on day 105,156 , 189,203 , respectively as compared to control. The existence of internal strain in treated silver is evidenced by change in unit cell volume and lattice parameter (Table 3). These internal strains made dislocations to move on the slip planes and intersecting slip planes built in stress concentrations. Furthermore, the stress concentration increases to such an extent causing the crystal to fracture at the sub boundaries and reduce the crystallite size. Our group previously reported that biofield treatment has significantly reduced the crystallite size in aluminium [30]. Furthermore, it is demonstrated that the rate of dissolution of a drug can be improved by choosing solids which exhibits high solubility due to low crystallinity or high amorphous phase [31]. Torrado et al. reported that solids with smaller crystallite size exhibited faster dissolution rate as compared to solids with higher crystallite size [32]. Thus, it is assumed that biofield treated silver powder may exhibit the higher dissolution rate in body fluid as compared to control, which ultimately can improve the bioavailability of dosage form containing silver.

\section{Surface area analysis}

Surface area of control and treated silver samples are presented in Table 4. Data exhibited that surface area of treated silver sample was increased from $1.70 \mathrm{~m}^{2} / \mathrm{g}$ (Control) to $2.54 \mathrm{~m}^{2} / \mathrm{g}$ on day 68 as compared to control. It indicates that surface area was enhanced by $49.41 \%$ as compared to control on day 68 after biofield treatment. It is well established that decrease in particle size of any powder enhance its surface area. Thus, the decrease in particle size leads to increase the surface area of treated silver powder after biofield treatment. Our group 
Citation: Trivedi MK, Tallapragada RM, Branton A, Trivedi D, Nayak G, et al. (2015) Physicochemical and Atomic Characterization of Silver Powder after Biofield Treatment. J Bioengineer \& Biomedical Sci 5: 165. doi:10.4172/2155- 9538.1000165

\begin{tabular}{|c|c|c|c|}
\hline Group & Control, day 0 & Treated, day 68 & Percent change \\
\hline Surface area & $1.70 \mathrm{~m}^{2} / \mathrm{g}$ & $2.54 \mathrm{~m}^{2} / \mathrm{g}$ & 49.41 \\
\hline
\end{tabular}

Table 4: Effect of biofield treatment on surface area of silver powder.

previously reported that biofield treatment has reduced the surface area in silicon and zirconium oxide [33,34]. Noyes-Whitney proposed the relationship between rate of dissolution $(\mathrm{R})$ and surface area $(\mathrm{S})$ of a solid as following [35]:

$$
R=\frac{D S\left(C_{s}-C\right)}{L}
$$

Where, $\mathrm{D}$ is diffusion constant, $\mathrm{Cs}$ and $\mathrm{C}$ are the concentration in the bulk dissolution medium and diffusion layer surrounding the solid, respectively, $\mathrm{L}$ is diffusion layer thickness. This equation revealed that the rate of dissolution can be modified primarily by altering the surface area of the solids. Thus, the large surface area of treated silver as compared to control indicates a higher dissolution rate of silver particles in surrounding fluid, which possibly improves the bioavailability. Moreover, it is reported that antimicrobial activity of silver is highly depended on its surface area since higher surface area causes large exposure to bacteria [36,37]. Thus, overall study suggest that bioavailability and antimicrobial efficacy of biofield treated silver might enhanced after biofield treatment.

\section{Conclusion}

Overall, biofield treatment has substantially altered the atomic and physicochemical properties of silver powder. Particle size data revealed that $\mathrm{d}_{10}, \mathrm{~d}_{50}, \mathrm{~d}_{90}$, and $\mathrm{d}_{99}$ of treated silver powder were significantly reduced up to $95.8,89.9,83.2$, and $79.0 \%$ on day 84 as compared to control. XRD results showed that unit cell volume and atomic weight was decreased up to $0.75 \%$, whereas density and nuclear charge per unit volume and density decreased up to $0.75 \%$ as compared to control silver on day 203. Also, the increase in nuclear charge per unit volume indicates that ionic strength of silver $\left(\mathrm{Ag}^{+}\right)$probably enhanced, which may improve its antimicrobial activity. In addition, crystalline size was reduced up to $70 \%$ in treated silver as compared to control on day 105 . Moreover, the decrease in particle size, increases the surface area up to $49.41 \%$ in treated silver powder as compared to control on day 68 . Thus, reduction in particle size, crystallite size and increase in surface area may increase the dissolution rate and thus bioavailability, which further attributes to antimicrobial efficacy of treated silver as compare to control.

\section{Acknowledgement}

Authors gratefully acknowledge to Dr. Cheng Dong of NLSC, Institute of Physics and Chinese academy of sciences for providing the facilities to use Powder $X$ software for analyzing XRD results.

\section{References}

1. Rehani MR, Joshi PB, Lad KN, Pratap A (2006) Crystallite size estimation of elemental and composite silver nano-powders using XRD principles. Indian J Pure \& Appl Phys 44: 157-161.

2. Cavalieri F, Tortora M, Stringaro A, Colone M, Baldassarri L (2014) Nanomedicines for antimicrobial interventions. J Hosp Infect 88: 183-190.

3. Guggenbichler JP, Boswald M, Lugauer S, Krall T (1999) A new technology of microdispersed silver in polyurethane induces antimicrobial activity in central venous catheters. Infection 27: 16-23.

4. Silver S (2003) Bacterial silver resistance: Molecular biology and uses and misuses of silver compounds. FEMS Microbiol Rev 27: 341-353.

5. Sondi I, Salopek-Sondi B (2004) Silver nanoparticles as antimicrobial agent: A case study on E. coli as a model for Gram-negative bacteria. J Colloid Interface Sci 275: 177-182.
6. Wani IA, Ganguly A, Ahmed J, Ahmad T (2011) Silver nanoparticles: Ultrasonic wave assisted synthesis, optical characterization and surface area studies. Mater Lett 65: 520-522.

7. Gurava AS, Kodas TT, Wang L, Kauppinen El, Joutsensaari J (1994) Generation of nanometer-size fullerene particles via vapor condensation. Chem Phys Lett 218: 304-308.

8. El-Noura KMMA, Eftaihab A, Al-Warthanb A, Ammarb RAA (2010) Synthesis and applications of silver nanoparticles. Arabian J Chem 3: 135-140.

9. Hasenohrl F (1904) On the theory of radiation in moving bodies. Annalen der Physik 302: 344-370.

10. Einstein A (1905) Does the inertia of a body depend upon its energy-content. Annalen der Physik 18: 639-641.

11. Becker RO, Selden G (1985) The body electric: Electromagnetism and the foundation of life. New York City, William Morrow and Company.

12. Trivedi MK, Tallapragada RM (2008) A transcendental to changing metal powder characteristics. Met Powder Rep 63: 22-28,31.

13. Dhabade VV, Tallapragada RM, Trivedi MK (2009) Effect of external energy on atomic, crystalline and powder characteristics of antimony and bismuth powders. Bull Mater Sci 32: 471-479.

14. Trivedi MK, Patil S, Bhardwaj $Y$ (2008) Impact of an external energy on Staphylococcus epidermis [ATCC 13518] in relation to antibiotic susceptibility and biochemical reactions - An experimental study. J Accord Integr Med 4 230-235.

15. Trivedi MK, Patil S (2008) Impact of an external energy on Yersinia enterocolitica [ATCC -23715$]$ in relation to antibiotic susceptibility and biochemical reactions: An experimental study. Internet J Alternat Med 6.

16. Trivedi MK, Patil S, Bhardwaj Y (2009) Impact of an external energy on Enterococcus faecalis [ATCC - 51299] in relation to antibiotic susceptibility and biochemical reactions - An experimental study. J Accord Integr Med 5 119-130.

17. Patil S, Nayak GB, Barve SS, Tembe RP, Khan RR (2012) Impact of biofield treatment on growth and anatomical characteristics of Pogostemon cablin (Benth). Biotechnology 11: 154-162.

18. Altekar N, Nayak G (2015) Effect of biofield treatment on plant growth and adaptation. J Environ Health Sci 1: 1-9.

19. Shinde V, Sances F, Patil S, Spence A (2012) Impact of biofield treatment on growth and yield of lettuce and tomato. Aust J Basic Appl Sci 6: 100-105.

20. Lenssen AW (2013) Biofield and fungicide seed treatment influences on soybean productivity, seed quality and weed community. Agricultural Journal 8: 138-143.

21. Sances F, Flora E, Patil S, Spence A, Shinde V (2013) Impact of biofield treatment on ginseng and organic blueberry yield. Agrivita J Agric Sci 35.

22. Trivedi MK, Patil S, Tallapragada RM (2012) Thought intervention through bio field changing metal powder characteristics experiments on powder characteristics at a PM plant. Future Control and Automation LNEE 173: 247 252

23. Trivedi MK, Patil S, Tallapragada RM (2013) Effect of biofield treatment on the physical and thermal characteristics of vanadium pentoxide powder. J Material Sci Eng S11: 001.

24. Trivedi MK, Tallapragada RM (2009) Effect of super consciousness external energy on atomic, crystalline and powder characteristics of carbon allotrope powders. Mater Res Innov 13: 473-480.

25. Lansdown AB (2002) Silver I: Its antibacterial properties and mechanism of action. J Wound Care 11: 125-30.

26. Panacek A, Kvitek L, Prucek R, Kolar M, Vecerova R, et al. (2006) Silver colloid nanoparticles: synthesis, characterization, and their antibacterial activity. J Phys Chem 110: 16248-16253.

27. Deng X, Nikiforov AU, Coenye T, Cools P, Aziz G, et al. (2015) Antimicrobia nano-silver non-woven polyethylene terephthalate fabric via an atmospheric pressure plasma deposition process. Sci Rep 5: 10138

28. Trivedi MK, Nayak G, Patil S, Tallapragada RM, Latiyal O (2015) Studies of the atomic and crystalline characteristics of ceramic oxide nano powders after bio field treatment. Ind Eng Manage 4: 161. 
Citation: Trivedi MK, Tallapragada RM, Branton A, Trivedi D, Nayak G, et al. (2015) Physicochemical and Atomic Characterization of Silver Powder after Biofield Treatment. J Bioengineer \& Biomedical Sci 5: 165. doi:10.4172/2155- 9538.1000165

Page 5 of 5

29. Prabhu S, Poulose EK (2012) Silver nanoparticles: Mechanism of antimicrobial action, synthesis, medical applications, and toxicity effects. Int Nano Lett 2:32.

30. Trivedi MK, Patil S, Tallapragada RM (2015) Effect of biofield treatment on the physical and thermal characteristics of aluminium powders. Ind Eng Manage 4: 151

31. Raza K, Kumar P, Ratan S, Malik R, Arora S (2014) Polymorphism: The phenomenon affecting the performance of drugs. SOJ Pharm Pharm Sci 1: 10.

32. Torrado G, Fraile S, Torrado S, Torrado S (1998) Process-induced crystallite size and dissolution changes elucidated by a variety of analytical methods. Int J Pharm 166: 55-63.

33. Trivedi MK, Patil S, Tallapragada RM (2014) Atomic, crystalline and powder characteristics of treated zirconia and silica powders. J Material Sci Eng 3: 144

34. Trivedi MK, Patil S, Tallapragada RM (2013) Effect of biofield treatment on the physical and thermal characteristics of silicon, tin and lead powders. J Material Sci Eng 2: 125.

35. Dokoumetzidis A, Macheras P (2006) A century of dissolution research: From Noyes and Whitney to the biopharmaceutics classification system. Int J Pharm 321: 1-11.

36. Amany A, El-Kheshen AA, El-Rab SFG (2012) Effect of reducing and protecting agents on size of silver nanoparticles and their anti-bacterial activity. Der Pharma Chemica 4: 53-65.

37. Nair LS, Laurencin CT (2007) Silver nanoparticles: synthesis and therapeutic applications. J Biomed Nanotechnol 3: 301-316. 